\title{
Forms of Empirical Observation and Argumentative Structures in Julien Offray de la Mettrie's Observations de médecine pratique (1743)*
}

Roberto Lo Presti

\section{Summary}

In this paper I examine one of Julien Offray de La Mettrie's most interesting, but also most neglected, medical works, Observations de médecine pratique (1743). I attempt both to assess its place in the wider context of eighteenth-century medical Empiricism and Neo-Hippocratism and also to understand to what extent La Mettrie's call for a medical practice based on observation can be considered as an expression of the long-term intellectual and epistemological process that culminated in the birth of clinical medicine.

Keywords: La Mettrie, Empiricism, Hippocratism, Observation, Materialism

Historians of philosophy and scholars of both intellectual and, to a lesser extent, medical history have long considered the thought and works of Julien Offray de la Mettrie as an intriguing subject of investigation. La Mettrie's writings can be revealing in many regards: they show, on the one hand, how the materialistic discourse on human nature took shape and spread throughout France and the rest of Europe in the eighteenth century, and, on the other, how this discourse prompted the elaboration, corroboration and dis-

* I am most grateful to the Alexander von Humboldt-Stiftung for its financial and institutional support. I also would like to thank Philip van der Eijk, my colleagues in the Berlin research group 'Medicine of the Mind, Philosophy of the Body', and Claire Crignon, who made many insightful comments on an early version of this paper.

Humboldt-Universität zu Berlin, Institut für Klassische Philologie, Unter den Linden 6, D-10099 Berlin (roberto.lo.presti@hu-berlin.de) 
semination of new ideas and influenced the development of the theoretical, epistemological and rhetorical models that laid the basis for the 'anthropological project' underlying the contemporary intellectual debate.

As an intellectual, La Mettrie was fascinating, protean and controversial: he was a philosopher, the author of polemical pamphlets and satire and a genuine esprit libertin, whose works frequently seem pervaded by a fundamental tension between universality and a lack of systematisation and chaos in some regards ${ }^{1}$. Yet, as Ann Thomson observes, 'he was first and foremost a doctor, and it was from his medical experience that La Mettrie's works stemmed and they were shaped by this experience'2. The central role played by medicine in the development of La Mettrie's intellectual world is evident if we consider the theoretical issues he dealt with all his life and the philosophical debates he took part in. In some cases, he made original contributions, yet he was not always completely understood and often even disregarded by his contemporaries. The debates in question concerned the physiological functioning of the body, the emergence of emotional and mental life in the human species and the relationship between the 'mental life' of men and the 'instinctual life' of animals.

La Mettrie's approach to all these crucial themes was characterised throughout by his strong materialism. In fact, the development of what I would call the 'theoretical, methodological and discursive triangle' of philosophical investigation, medical empiricism and materialism is absolutely essential to La Mettrie's thought. To get an idea of how close the link between La Mettrie's materialistic Weltanschauung and his valorisation of experience was, it suffices to read two passages of the Discours préliminaire, which La Mettrie wrote as an introduction to his Oeuvres philosophiques, published posthumously in 1751 :

Philosophy, on the study of which everything depends, depends in turn on Nature, just as a daughter depends on her mother. It has this in common with true medicine, namely, that it considers this slavery as an honour, knows nothing else and heeds no other voice. All that is not drawn from Nature's bosom, all that is not phenomena, causes, effects - in a word, the science of things - does not concern Philosophy and comes from a source that is foreign to it. ${ }^{3}$

1 La Mettrie's manner of thinking is well exemplified by what he wrote in his Les Animaux plus que machines. See La Mettrie 2004, 216: 'Une douzaine de contradictions nous semblent une bagatelle, tant l'art est difficile'. On the influence of libertine culture on La Mettrie's thought and style, see Reichler 1984, 73-82 and 57-69; Bloch 1992, 73-82; Macchia 1994, 207-211.

2 Thomson 1981. On La Mettrie's life and work see Boissier 1931; Lemée 1954; Wellman 1992; Pénisson 2006, 91-99; Gougeaud-Arnaudeau 2008.

3 La Mettrie, Discours préliminaire, in Thomson 1981, 207: 'La Philosophie, aux recherches de laquelle tout est soumis, est soumise elle-même à la Nature, comme une fille à sa mère. Ella a cela de commun avec la vraie médecine, qu'elle se fait honneur de cet esclavage, qu'elle 
And also:

But writing as a philosopher is to teach materialism! Well then! How terrible! If this materialism is well-founded, if it is the obvious result of all the observations and experiences of the greatest philosophers and doctors; if one embraces this system only after having attentively followed Nature, assiduously walked in her footsteps through the entire extent of the animal kingdom and, so to speak, after having studied Man intently in all his ages and in all his states? If orthodoxy follows the philosopher rather than him avoid it; if he neither looks for nor intentionally forges his doctrine, if he somehow finds it, while he is in the midst of his research and on its track, is it therefore a crime to publish it? It not truth itself worth bending down, as it were, to pick it up? ${ }^{4}$

Paraphrasing these texts, we can say that in La Mettrie's eyes being a philosopher means being a materialist, and being a materialist is the result of observation and experience or, more precisely, the result of the medical inquiry. The question as to the heuristic and argumentative function of experience in La Mettrie's écrits philosophiques and consequently the role medicine plays in these works, considering that 'La Mettrie was first and foremost a doctor's, however, remains open. It has been pointed out that the basic concepts and most original insights of La Mettrie's philosophical works - I am thinking of the notion of 'organisation', the link established between the emergence of intelligence, the structure of the brain, the reduction of the instinctual sphere and the linguistic function, and also La Mettrie's conception of the biological world as a continuum of differentiated beings - stem directly from the collection, analysis and critical interpretation of the observations of contemporary medical research ${ }^{6}$. And yet La Mettrie's empirical method is not free from contradictions and shortcomings: in fact, although it is based on a clear distinction between 'expérience bien fondée' and 'blind empiricism' - that is, an empiricism that does not subsume the results of observation under a 'scientific' frame of knowledge -, this method often wavers perilously between the interpretation and over-interpretation of experiential evidence and thus between observation, on the one hand, and abstract speculation, on the other.

n'en connoit point d'autre, et n'entend point d'autre voix. Tout ce qui n'est pas puisé dans le sein même de la Nature, tout ce qui n'est pas phénomènes, causes, effets, science des choses en un mot, ne regarde en la Philosophie, et vient d'une source qui lui est étrangère'.

4 Thomson 1981, 215: 'Mais écrire en Philosophe, c'est enseigner le Matérialisme! Eh-bien! Quel mal! Si ce matérialisme est fondé, s'il est l'évident résultat de toutes les observations et expériences des plus grands Philosophes et Médecins ; si l'on embrasse ce système, qu'après avoir attentivement suivi la Nature, fait les mêmes pas assidüement avec elle dans toute l'étendue du règne animal, et, pour ainsi dire, après avoir approfondi l'Homme dans tous ses âges et dans tous ses états? Si l'orthodoxie suit le Philosophe plutôt qu'il ne l'évite; s'il ne cherche ni ne forge exprès sa doctrine, s'il la rencontre en quelque sorte, qu'elle se trouve à la suite de ses recherches et comme sur ses pas, est-ce donc un crime de la publier? La vérité même ne vaudroit-elle donc pas la peine qu'on se baissât en quelque sorte pour la ramasser?'

5 Thomson 1981, 21.

6 See Wellman 1992, 169-212. 
The historical and epistemological study of La Mettrie's medical works has not been conducted with the same attention and analytical depth as in case of La Mettrie's philosophical works ${ }^{7}$. This is surprising for several reasons: first, because La Mettrie's intellectual formation was firstly and foremostly medical rather than philosophical. One might even say that $\mathrm{La}$ Mettrie became a philosopher only insofar as he learnt how to think about human nature as a doctor. Secondly, the discrepancy is surprising, because texts like Traité du vertige (1737), Mémoires sur la dysenterie (1750), Traité des maladies vénériennes (1735) and Observations de médecine pratique (1743) are extremely rich in theoretical suggestions and methodological discussions; they in fact contain in embryonic form most of the ideas that $\mathrm{La}$ Mettrie developed in a more complex and articulate form in his formal philosophical works. It is no coincidence, I believe, that in $1751 \mathrm{La}$ Mettrie had planned the publication of his collected works in two distinct volumes, one containing his Euvres philosophiques, the other his Euvres de médecine, both of which were published posthumously ${ }^{8}$. This plan testifies to the unity and coherence of his research interests. Therefore, if one considers La Mettrie's medical works as a step in a life-long process of intellectual formation; in other words, if one considers these works as a kind of 'conceptual laboratory' and tries to investigate both their contents and argumentative structures, it will be possible to cast new light on La Mettrie's materialism as well as on his adherence to methodological empiricism and to understand how the notions of 'experience', 'observation' and 'experimentation' interact and ultimately serve as powerful heuristic and polemical tools in a strongly anti-dogmatic philosophical framework.

The questions I intend to pose concern the theoretical, formal, and rhetorical aspects of La Mettrie's medical texts. First of all, we must explore how La Mettrie characterizes his own empiricism and whether he draws a distinction - and, if so, to what extent - between the empirical method and the medical empiricism traditionally associated with Hippocratism ${ }^{9}$. It is also necessary to investigate to what extent in his medical works La Mettrie moves from a strictly medical and observational level to a more speculative one, and, consequently, how we might describe the interplay between experience and theory and the tension between dogmatism and anti-dogmatic polemic.

7 For a survey of La Mettrie's medical works, see Wellman 1992, esp. chaps. 4 (85-106) and 5 (107-134); Thomson 1981, 21-32; Gougeaud-Arnaudeau 2008.

8 La Mettrie published an initial, incomplete collection of his philosophical works in 1751 . The complete edition of his Oeuvres philosophiques was published posthumously in 1752, while the volume of La Mettrie's Oeuvres de Médecine did not appear until1755.

9 For a history of Hippocratism and the various 'Hippocratisms' that succeeded one another in the history of western medicine, see Smith 1979 and Cantor 2001. 
Another issue concerns the relationship between the notions of 'phenomenon' and 'cause': to what extent does La Mettrie address the definition of a systematic aetiology and how does he approach the epistemological problem raised, both for the physician and for the philosopher, by the need/will to make sense of the 'unknown' and of what is not directly observable? Finally, we should address the issue whether, already in his medical works, La Mettrie shows awareness of what became at a later stage of his intellectual journey the core of his philosophical inquiry, namely, the nature of the relationship between physiological functions and mental activity ${ }^{10}$.

As far as the formal structure of these texts is concerned, it is worth investigating to what extent the use of polemic as a rhetorical/heuristic strategy is characteristic of La Mettrie's medical oeuvre; in what circumstances and to what extent the author's 'ego' is perceptible in these texts; whether La Mettrie explicitly addresses the reader, and how the reader is represented; and what strategies are adopted to legitimate and corroborate experience.

In this paper I shall try to address most, if not all, of these questions by focusing on one of La Mettrie's most interesting and yet most neglected medical works, namely, Observations de médecine pratique, published in Paris in $1743^{11}$. Observations de médecine pratique is written as a record of the daily practice of a physician, containing observations on a wide variety of diseases and of case histories. Already the title of the work illustrates the prominent role that La Mettrie attributes to the empirical practice of medicine from an epistemological and a pragmatic point of view. We are in presence of 'observations' - therefore, systematic knowledge developed through bedside practice - that are entirely and explicitly incorporated into a 'practical' framework (which explains the second key term of the title), that is to say a framework in which discussion of how to treat diseases and, more concretely, how to treat individual patients holds an absolutely central place.

This interpretation of the title as a profession of faith in Empiricism is also confirmed by the structure of the text, which is organised in two sections: the first (chaps. 1-8) contains general descriptions of well-defined diseases such as cholera, pox, smallpox, measles and pertussis. These descriptions are characterized by the attempt to arrange several individual observations in the framework of a natural history of epidemic diseases. The second section (chaps. 9-33) constitutes what might be described as a 'collection of case histories' recorded by

10 Works like L'Homme-Machine and Les animaux plus que machines revolve entirely around this problem.

11 Julien Offray de la Mettrie, Observations de médecine pratique (Paris: Huart, 1743). 
La Mettrie because of the exceptional or, on the contrary, paradigmatic nature of their symptoms and evolution, because of the therapy adopted to treat them and because of the mistakes made by other doctors in devising a treatment.

Of course, the Observations must also be situated in the wider context of medical texts informed by the principles of empiricist epistemology written between the end of the seventeenth and the first half of the eighteenth century. In this connection, one has to refer to the writings of the two doctors whose doctrines and views on matters of medical practice and medical epistemology strongly influenced La Mettrie when he was being trained as a doctor: Thomas Sydenham and Herman Boerhaave ${ }^{12}$. The very title Observations de médecine pratique clearly echoes that of one of Sydenham's most famous and influential works, Observationes medicae. In this work, the so-called 'English Hippocrates' put into practice a method of observing and describing diseases that Sydenham himself represented as coherent with, and even modelled after, the example set by the Hippocratic Epidemics ${ }^{13}$. And Hippocrates is in fact the third name that should be mentioned as a source of inspiration for La Mettrie's Observations.

The 'Hippocratic' inspiration of La Mettrie's Observations should not, in my view, be considered as the result of a 'second-degree relation', so to speak, that La Mettrie established with the Hippocratic model as mediated by Sydenham and Boerhaave's own understanding and revival of the Hippocratic methodological principles. In other words, the 'Hippocratism' of La Mettrie's Observations not only seems to go far beyond that of both Sydenham and Boerhaave, but the structure of La Mettrie's Observations also departs in some fundamental regards from the principles of the other medical empiricists, whose claim to follow Hippocrates was often paired with the ambition of bringing the Hippocratic method of observation to a higher level of perfection ${ }^{14}$. This emerges most clearly if we consider how Sydenham structured his account of epidemic diseases and then observe the structure of La Mettrie's Observations. First, what distinguishes Sydenham's account of 'epidemic' diseases most clearly from the Hippocratic model is Sydenham's constant preoccupation with nosological entities of a definite nature. He observes diseases and, through his observations, provides a natural history of them, not the histories of individual patients ${ }^{15}$. By contrast, an 'epidemic constitution' in the Hippocratic corpus always consists

12 See Wellman 1992, 60-134.

13 On Sydenham's Hippocratism, see Dewhurst 1966, 60-67; Brinkmann 1970. On the 'ancient' roots of Sydenham's empiricism, see also Hesse 1970. On the rising importance of the notion of 'observation' in the early modern neo-Hippocratic milieu see Pomata 2011, 45-80. 14 See Daston/Lunbeck 2011, 3-4.

15 Duchesneau 1973, 8-15. 
first and foremost of an ensemble of individual histories framed in a broader observational context, which the histories themselves help to shape ${ }^{16}$. Second, the overall architecture of La Mettrie's Observations suggests a direct link to the Hippocratic Epidemics, in that La Mettrie adopts the distinction between 'pathological constitution' of a city or a region (katastasis) and individual 'patient history', on which above all books I and III of Epidemics are based ${ }^{17}$. In this regard, it is important to note that the Hippocratic Epidemics are not a unitary text or a homogeneous collection. There are in fact clear differences between the seven books of the collection of Epidemics both in terms of style and language and as regards the selection and organisation of the empirical evidence. To give an example, the above mentioned distinction between 'constitutions' and 'case histories', which provides the theoretical background of books I and III, is not found in the other five books; books V and VII, in turn, are characterised by the remarkable accuracy and linguistic richness in accounts of symptoms and the evolution of pathological processes, as well as by frequent and quite detailed discussion of therapy-related issues ${ }^{18}$.

This heterogeneity allowed many doctors and medical authors - including La Mettrie - to consider this milestone of the western medical tradition as an 'open model', the adoption of which often amounts to a more or less explicit process of adaptation and reinvention. As for La Mettrie, shedding light on the most significant aspects of this process of reinvention may give us with new insight into some key moments of the intellectual journey that culminated in La Mettrie's adherence to the empirical method in both medicine and philosophy.

The Hippocratic inspiration of Observations de médecine pratique seems to be confirmed by certain theoretical, formal and methodological/rhetorical aspects of La Mettrie's text.

1. As regards the theoretical aspects, it is immediately clear that the nosological and semiotic categories adopted by La Mettrie are often taken directly from a tradition that stems from the Epidemics: this is the case, for example, of the classification of fevers as 'continuous', 'tertian' or 'semitertian', etc., and of the theory of 'critical days' on which this classification is based ${ }^{19}$. Moreover, the etiological reference system that frames La Mettrie's obser-

16 See Pigeaud 1988, 305-329.

17 On the concept of katastasis, see Grmek 1994.

18 On the structural and theoretical features of the Hippocratic Epidemics see Deichgräber 1933; Langholf 1990; Jouanna 2003, 7-90; Alessi 2010, 119-135.

19 On the Hippocratic classification of fevers see Yeo 2005, 433-443. On the theory of the "critical days' see Langholf 1990, 73-117. 
vations coincides almost entirely with the Hippocratic theories of the humoral constitution of the human body and the pathogenic effect of climatic variations, especially excessively violent and abrupt variations; more generally, La Mettrie's reference system coincides with an 'environmental' conception of the processes that determine states of health and disease ${ }^{20}$.

2. With regard to the formal aspects, it is remarkable that La Mettrie's 'clinical observations' and some of the 'case histories' found in the Hippocratic Epidemics (above all those contained in books V and VII) generally follow the same narrative principles. This is true above all with reference to the individuation and characterization of pathological symptoms that should be understood as 'signs' and with reference to the 'contextualization' of the therapeutic procedures adopted. In order to understand to what extent this parallel can be drawn, it will suffice to compare a chapter of La Mettrie's Observations to two brief chapters from the seventh book of Epidemics:

OMP, chap. 27 (J. Offray de la Mettrie, Euvres de Médecine (Berlin, 1755), 322): Woman... five months pregnant, vomiting almost uninterruptedly, was attacked by a continuous fever with recrudescence, massive vomiting more frequent than ever and delirium. She was bled three times in the arm and purged five times under the effect of a very mild laxative. The vomiting was calmed and recrudescence was prevented by using Cinchona and mild narcotics, given early in the evening. Simple tisanes and light broths were the only food. Urine always flowed freely and always extremely cloudy... Very fortunately, this woman safely delivered her baby at full term ${ }^{21}$.

Epid. VII, 94 (p. 106, 3 Jouanna): Theotimus' wife, in a semitertian, had nausea and vomiting; shivering at the time the fever began, and thirst. As time went on, and even at its beginning, the fever was extraordinary. When she drank melicrat and vomited, her shivering and nausea stopped. And later [she drank] the solution from pomegranate skin (trans. Smith) ${ }^{22}$.

Epid. VII, 102 (p. 108, 16 Jouanna): Pausanias' young daughter, when she ate a raw mushroom, had nausea, choking, pain in the stomach. Drinking warm melicrat and vomiting helped, and warm bathing. In the bath she vomited the mushroom and when she was about to recover she sweated (trans. Smith) ${ }^{23}$.

20 See von Brunn 1946-1947, 151-173; Pinna 1988, 3-19; Staszak 1995.

21 'Madame... grosse de cinq mois, vomissant presque sans cesse, fut attaquée d'une fièvre continue avec redoublement, vomissements énormes, plus fréquents que jamais, et délire. On la saigna trois fois au bras, on la purgea cinq fois avec un minoratif très doux. On calmait les vomissements et on prévenait les redoublements par l'usage du Quinquina, et des narcotiques doux, donnés le soir de bonne heure. Tisanes simples, et bouillons clairs, pour toute nourriture. Les urines coulèrent toujours en liberté, et toujours fort chargées... Cette Dame accoucha fort heureusement à son terme'.

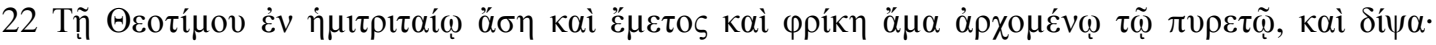

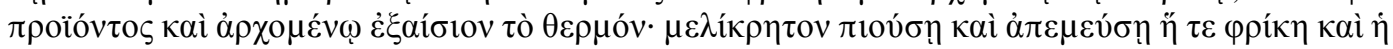

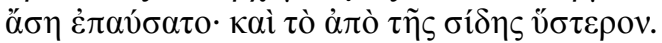

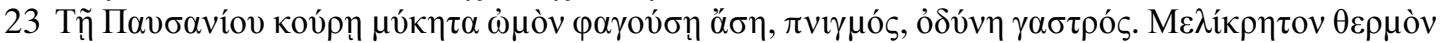

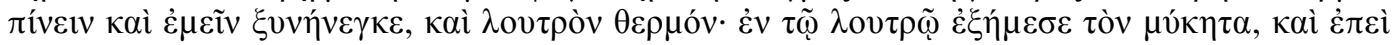

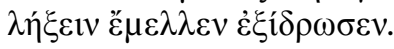


3. As far as rhetorical and methodological issues are concerned, it is precisely in regard to therapeutics that a second clear trace of continuity between La Mettrie and the Hippocratic model may be found. For there is no substantial difference between the ancient remedies and those suggested by La Mettrie, the arsenal of possible treatments being more or less the same: bloodletting, fumigations, tisanes, purgative or emetic beverages, laxative and narcotic herbs ${ }^{24}$.

Another important element shared by both La Mettrie's Observations and the Hippocratic Epidemics - important especially with respect to strategies of corroborating and validating the body of experiential evidence - is the adoption of what might be described as the 'rhetoric of error'25. Observational mistakes are recorded, discussed and explained, on the one hand, for the clearly rhetorical purpose of strengthening and legitimating the author's point of view; on the other hand, the reasoned account of medical mistakes also serves a methodological and epistemological purpose, insofar as it paves the way, by means of concrete examples, toward reflection on the nature and limits of medical practice: a practice that must always confront its own fallibility and be able to combine, in every single observational act, a gaze free from any abstract speculation and a body of knowledge that is, historically speaking, posterior to that gaze, but, logically speaking, anterior. However, a substantial difference may also be found: in the fifth book of the Hippocratic Epidemics (chaps. 27-30) we are told of mistakes made by the same doctor who wrote these notes ${ }^{26}$; La Mettrie, on the contrary, reports only mistakes made by other doctors, often in a very polemical and even sarcastic tone ${ }^{27}$. La Mettrie's decision to do so hints at the role played by the 'ego' of the doctor, who is considered both as an 'observer', insofar as the very process of struc-

24 On the Hippocratic pharmacology see Totelin 2008.

25 See Lo Presti 2010a, 137-167.

26 In Epidemics $V, 27$ we find an account of a diagnostic error: a certain Autonomus, deceased on account of a head wound, should have been treated with trepanning. But, the physician admits, 'I did not notice that the sutures had the injury of the weapon right on them, since it became obvious only later'. Following this, in chap. 28 , a case is presented involving a girl with a head wound. In this case, whilst trepanning was indeed carried out, the intervention was too superficial and caused the wound to suppurate. In chaps. 29 and 30 we find two cases of delayed cauterization in which the patients died.

27 A perfect example of La Mettrie's polemic against the mistakes due to the incompetence of some doctors is to be found in chap. 10 (Oeuvres de médecine, p. 310): '... Opération qui a été faite avec succès plus d'une fois. Nous croyons donc que si on l'eût fait de bonne heure à la Dame dont je parle, on auroit pû la guérir; mais le Médecin traitant ne connut son mal qu'à la mort; il prit cette Hydropisie pour une hydropisie ordinaire, faute de faire attention aux signes absens et pressens, tandis que sur les seuls bruits de la Ville, tous les autres Médecins soupçonnoient un dépôt dans la duplicature du péritoine; d'où l'on voit l'utilité d'assembler plusieurs Médecins, quand on n'en pas un bon, et celle d'ouvrir ceux qui meurent de maux extraordinaires'. 
turing medical experience is concerned, and as an 'author', when the representation of observational practice is at stake. Once again it suffices to read La Mettrie alongside the text of Epidemics to get an idea of both the commonalities and differences between Observations de médecine pratique and their ancient model:

OMP, XI (J. Offray de la Mettrie, Euvres de Médecine (Berlin, 1755), 311): A sturdy farmer suffered massive bleeding from the anus; the surgeons responsible for examining the haemorrhage concluded that it came from the rectum, where they claimed they could feel a carcinomatous tumor... He died a few days later; he was opened up, and it was discovered that it was nothing but a haemorrhoidal vessel that had ruptured just inside the anus; consequently, it would have been easy to stop the bleeding by means of styptics, if only the surgeons had had the skill to find the vessel ${ }^{28}$.

Epid. V, 27 (p. 16, 20 Jouanna): Autonomus in Omilus died on the sixteenth day from a head wound in midsummer. The stone, thrown by hand, hit him on the sutures in the middle of the bregma. I was unaware that I should trephine, because I did not notice that the sutures had the injury of the weapon right on them, since it became obvious only later (trans. Smith) ${ }^{29}$.

These two points - the presence of the author's ego in the text and the tension or interplay of observation and abstract knowledge - help us to appreciate the idiosyncrasies and limitations of La Mettrie's empiricism, as well as its degree of originality with respect to the Hippocratic Epidemics.

We may begin with the 'narrative function' performed by the 'observer' in La Mettrie's text. In contrast to the Epidemics, where the medical author gives shape to a narrative in which he merely plays the part of an external observer, La Mettrie's rhetorical and epistemological strategy consists in adopting self-observation as the basis and origin, so to speak, of his empirical method. The first chapter of Observations de médecine pratique (it is in fact one of the longest and most detailed chapters of the entire work) is entirely devoted to a description of cholera, which La Mettrie has experienced both as patient and as a doctor attempting to heal himself and to describe and rationalize his own subjective perception of the disease. La Mettrie's own words on the subject are illuminating:

28 'Un paysan robuste perdoit beaucoup de sang par l'anus; les Chirurgiens chargés d'examiner l'hémorrhagie, conclurent qu'elle venoit du rectum, où ils disoient toucher une tumeur carcinomateuse... Le malade mourut en peu de jours; on l'ouvrit, et on trouva que ce n'étoit qu'un vaisseau hémorrhoidal qui s'étoit ouvert à l'anus un peu intérieurement; ainsi il eût été facile d'arrêter le sang par les stiptiques, si les Chirurgiens eussent eu l'adresse de trouver le vaisseau'.

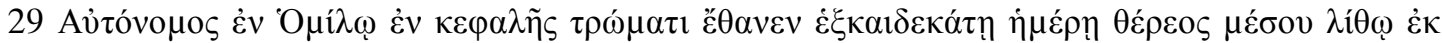

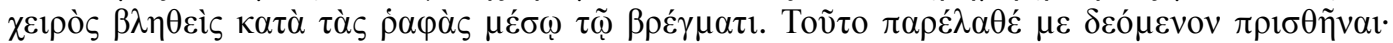

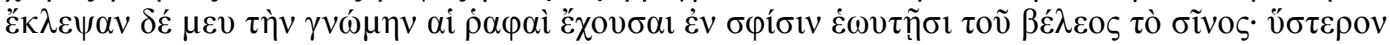

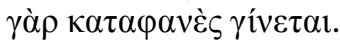


Last August $15^{\text {th }}$, I myself experienced this terrible alternation [between vomiting and evacuations below] with such strange and unusual accidents, (and) I escaped their fury by means of such bold a treatment, that everything compels me to give an account of the disease that made such an extremely cruel attack on me. One feels a kind of pleasure in telling of its wreck in the harbour ${ }^{30}$.

In this way the experience, which La Mettrie reports as the basis of his medical knowledge and therapeutic strategies, becomes a reflexive experience, the validity of which derives from a combination of objective and subjective aspects. But this strategy should not be dismissed as merely an expression of a hypertrophic ego. For, to La Mettrie's eyes, this 'subjectivizing gaze' represents the point of departure of his first medical reflections on the relationship between physiological and cognitive functions, a relationship that $\mathrm{La}$ Mettrie's later philosophical investigations would revolve around almost entirely. To understand in what terms and to what extent this 'principle of subjectivity' serves as the epistemological foundation of La Mettrie's whole method of inquiry, it is useful to read a passage of the first chapter of the $\mathrm{Ob}$ servations, in which La Mettrie describes his psychophysical state after a series of bloodlettings he had decided to undergo:

I had little blood left in my vessels, but it rushed at an inconceivable speed; my imagination and my mind kept pace; I have never had more vivid ideas and a more striking vision of objects. Sensitive, impatient, full of a new fire, I was captivated by my inebriated state of mind, and I had to bleed massively to escape it ${ }^{31}$.

We may turn now to questions concerning the relationship established by $\mathrm{La}$ Mettrie between observation and previously acquired knowledge in Observations de médecine pratique. Epidemics provided the fundamental model also in this respect, especially in regard to the following two points: 1) 'clinical' observation always acts on the surface of the body by connecting and ordering series of phenomena without immediately attempting to determine the cause. In this perspective, which Sydenham had wholeheartedly adopted in his clinical practice, the meaning of a 'clinical history' is not derived from an inquiry into the internal structures of the body, but rather from the composition and decomposition of signs and symptoms, that is to say from their syn-

30 La Mettrie 1755, 270: 'J'éprouvai moi-même le 15 Aout dernier (1741) cette terrible alternative [entre vomissements et évacuations par le bas] avec des accidents si bizarres et si singuliers, j'échappai à leur fureur par un traitement si hardi, que tout m'invite à donner l'histoire d'une maladie, dont j'eus la plus cruelle atteinte. Il y a un certain plaisir à raconter son naufrage dans le port'.

31 La Mettrie 1755, 275: 'Il me restoit peu de sang dans les vaisseaux, mais il y galopoit avec une vitesse inconce[v]able; mon imagination et mon esprit suivoient le même train; jamais je n'ai eu d'idées plus vives, ni de peinture plus frappante des objets. Sensible, impatient, plein d'un feu nouveau, j'étois enchanté de l'ivresse de mon état, et il me falloit faire bien du sang pour en sortir'. 
tax or, in Foucaultian terms, their algebraic analysis ${ }^{32}$.2) The tension between individualisation and generalisation cannot be reduced to a dialectic between abstract nosological entities and individual cases. The epidemic 'constitutions' result from analysis of coincidental, regular and exceptional phenomena that can be observed in a definite context at a definite time. The 'constitutions' are therefore characterised as cognitive spaces by being extraneous to any ontological conception of the disease: they in fact represent a space in which every single pathological symptom may have a semeiotic value without necessarily being indicative of a specific disease ${ }^{33}$.

In La Mettrie's Observations these two cruxes of the Hippocratic empirical tradition are harshly criticised and substantially rethought. La Mettrie conceives of observation as an intellectual practice whereby clinical evidence is interpreted in light of actual or presumed knowledge of an anatomical change corresponding to a symptom, and each individual case is judged through the lens of abstract nosological categories. It is in this perspective that we should understand La Mettrie's polemic against 'ceux qui voient beaucoup de malades, mais voient ordinairement peu de maladies' (OMP, in Oeuvres de médecine, p. 277). It is also in this perspective that we should understand the frequent polemical references to Sydenham, who was a champion of this extreme form of empiricism and whose errors both in observational practice and in treatment are ironically stigmatised by La Mettrie ${ }^{34}$. For his part, La Mettrie always tries to establish and describe the general features - one might also say the specific nature - of a pathological entity, before taking individual cases into account. This is the strategy he adopts when discussing diseases like cholera, dysentery (to which La Mettrie also dedicated a monograph), whooping cough and malignant fevers. The construction of 'reasoned experience', however, is based not only on these strategies for gen-

32 Foucault $1983^{5}, 87-105$.

33 On the ancient concept of disease and especially on the ancient clinical entities and their classification see Grmek 1993, 338-342; Pigeaud 1996, 785-792.

34 See, for example, chap. 1 (La Mettrie 1755, 277): 'Tout le résultat de cette Histoire, est en faveur de la saignée, des Bains, des Boissons rafraichissantes, et du Laudanum. Mais quelque grand usage qu'en fit Sydenham dans le Cholera-Morbus, comme dans tant d'autres maladies, on voit en même tems, avec quel ménagement, avec quelle prudente et sage lenteur, il faut emploier ce dernier remède; car avant tout c'est la cause première et générale d'une maladie, qu'il faut découvrir et attaquer'; chap. 6 (La Mettrie 1755, 292): 'J'ai vû des faits qui m'ont enfin ouvert les yeux sur la Doctrine de M. Freind, et je me retracte toujours avec plaisir en faveur d'une vérité bien reconnue: j'ai aussi compris que pour purger, il ne faut compter aussi scrupuleusement les jours, que le bon Sydenham; il en faut venir là hardiment, dès que les circonstances l'éxigent ... J'ai vu des malades, attaqués de petites véroles confluentes, sans nulle enflure, et sans nul ptyalisme, pendant tout le cours de la maladie; et cependant plusieurs échapoient à ces mauvais symptômes, que Sydenham regarde toujours comme mortels'. 
eralizing observational evidence, but also on the search for differences and more precisely for distinctive symptoms. This is the case in the seventh chapter of the Observations, in which La Mettrie explains how to distinguish between measles and smallpox on a clinical basis:

Thus, before the outward signs of this disease appear, it is difficult to predict whether one will have measles or smallpox, because these two diseases indeed have common symptoms; and even when these signs become manifest, how can one distinguish them [signs of measles], if they are, as is sometimes seen, as pronounced as smallpox blisters? For the cough: sometimes one vomits in both diseases, but it is rare to cough in either of them, and if this should happen, there would be differences so that an experienced physician could not be mistaken ${ }^{35}$.

It is clear that both strategies - generalization and differentiation - adopted by La Mettrie presuppose an ontological conception of disease. This conception, in turn, entirely depends on the theoretical premise that the clinical specificity of a disease reflects an anatomical specificity (that is, a specific organic lesion) that can be detected by post-mortem examination. And in fact La Mettrie relies on anatomical arguments as the ultimate source of legitimacy for clinical observations and as the very basis of reliable diagnostic practice extremely frequently in his Observations. By way of example, I will quote a passage from the fifth chapter on pertussis:

Through careful examination of these diseases [whooping coughs], I have come to the conclusion that it is nothing but a convulsive movement produced in the muscles of the larynx by an abundant melt of acrid mucus, which irritates the lungs so severely that they suffer the most suffocating coughs and most extraordinary jolts. Nevertheless one is surprised to see that lungs are never inflamed; the fact is that these same jolts clear this organ and it is in the brain, which is the softest part and the most prone to congestion, that the inflammation is produced, as I have learnt from anatomical examination ${ }^{36}$.

With regard to the epistemological status of the concept of experience, the question we must raise once again concerns the logical and temporal order of clinical and anatomical observations. While it is true that the latter provides a framework of knowledge that ultimately results in an aetiological the-

35 La Mettrie 1755, 299: 'Ainsi avant que les marques extérieures de ce mal paroissent, il est difficile de prédire, si c'est la rougeole, ou la petite vérole qu'on aura, puisqu'en effet ces deux maladies ont bien des symptômes communs; et lors même que ces marques se manifestent, comment les distinguer, si elles sont, comme on le voit quelquefois, aussi élevées, que des grains de petite vérole? Par la toux: on vomit quelquefois dans l'une, comme dans l'autre maladie; mais il est rare qu'on tousse dans les deux, et si cela arrivoit, ce seroit toujours si différemment, qu'un Praticien exercé ne pourroit s'y méprendre'.

36 La Mettrie 1755, 287: 'En examinant attentivement ces maladies [les coqueluches], je me suis persuadé, que ce n'étoit qu'un mouvement convulsif, produit dans les muscles du Larinx, par une fonte abondante de pituite âcre, dont le poumon est si fort irrité, qu'il est sujet aux toux les plus suffocantes, et aux secousses les plus extraordinaires. Cependant on est surpris que le poumon ne s'enflamme jamais; c'est que ces mêmes secousses débarrassent ce viscère, et c'est dans le cerveau, la partie la plus molle, et la plus aisée à s'engorger, qu'il se fait l'inflammation, comme l'examen anatomique me l'a appris'. 
ory and must therefore be considered as anterior to clinical observation from a strictly logical point of view, it is nevertheless clear that, from a temporal point of view, anatomical investigation can take place only at the end of a clinically observable pathological process, and more precisely only at the end of a pathological process that culminates in the patient's death. The epistemological consequences of this distinction between the logical and temporal order of the observations are very important. The simple fact that clinical evidence is analyzed in light of the results of a post-mortem anatomical examination is in and of itself not sufficient to establish a reliable empirical method, nor is it sufficient to develop a coherent, anatomically based aetiological classification of diseases. The reason for this insufficiency is that postmortem dissection cannot produce an observational context in which the 'original' anatomical lesion that caused a disease appears with absolute clarity. The only thing it can offer is an open field (the dissected body) in which it is possible to observe a number of organic changes, the origin, connections and succession of which remain utterly unclear, unless the observer has a key to decipher and impose order on the 'objects' amassed in this open field.

When reading the references to anatomical examinations in La Mettrie's Observations de médecine pratique, one gets two different, contradictory impressions: on the one hand, La Mettrie's attempt to 'embed' anatomical observation in a theoretical and methodological framework clearly inspired by 'empiricist' and 'Hippocratic' principles seems quite at variance with the doctrine of other forms of philosophical and medical empiricism. One might think, for example, of the open scepticism with which two empiricists like Sydenham and Locke regarded all forms of anatomically based investigation of the remote causes of a disease ${ }^{37}$. This difference between La Mettrie and two figures with whom he had very much in common in many other regards $^{38}$ can be better appreciated if one considers it in connection with, and in light of, another point of disagreement between La Mettrie and the two champions of English medical and philosophical empiricism. Sydenham and Locke's broad dismissal of anatomy as a key to a scientific understanding of the causes of health and disease was the consequence of their acceptance of a mechanistic conception of the ultimate, imperceptible structures of reality underlying the domain of phenomena ${ }^{39}$. By contrast, La Mettrie's reappraisal of the epistemic value of anatomy as a key to living matter that emerged from

37 Duchesneau 1973, 33-41 and 68-83. On Locke's theory of causation, see also Jacovides 2007, 101-129.

38 On La Mettrie's reception of Locke's theory of knowledge, see Wellman 1992, 135-168.

39 Duchesneau 1973, 15-33. For a very rich and detailed analysis of Locke's views on, and rejection of, anatomy see Crignon 2016, chap. 4. 
and consisted in complex, differentiated and organized structures is based on and, at the same time, provides a source of legitimation for a radical challenge to the mechanistic conception of vital processes and their pathological alterations ${ }^{40}$. In this respect, the way in which experience is 'constructed' in La Mettrie's Observations reflects the distinctive manner of thinking of eighteenth-century French materialists.

Yet, when reading La Mettrie's Observations, it is clear that, in the rhetorical frame of this text, dissection serves to provide confirmation ex post rather than a basis for clinical experience ${ }^{41}$. In order to fully appreciate the difficulties encountered by La Mettrie in attempting to draw a clear and unambiguous distinction between concomitant or concurrent phenomena and phenomena connected by a proper causal relation - and therefore to distinguish between the rhetorical and epistemological function of the notion of 'cause' - it suffices to read a passage of the eighth chapter of the Observations, in which La Mettrie discusses a variety of measles that he designates 'new measles' (rougeole nouvelle):

Afterwards, just before death, completely dissolved and serous blood flowed from the mouth and nose, and blood drawn from the vein exhibited all the signs of an alkalescent scurvy. From this it follows, in my opinion, that this disease had eaten away, destroyed and opened some blood vessels, and that it was a gangrenous and scorbutic dissolution of all the blood that had caused all the ravages I saw when opening the body: the large lobe of the liver was lined with a pale gangrene, the mesentery and above all the pancreas Aselli were completely corrupted, and there was much extravaseted blood ${ }^{42}$.

As has been remarked by M. Foucault in his book Naissance de la clinique, an actual synthesis of clinical and anatomical observation was made possible only by the development of the highly sophisticated form of medical empiricism known as the anatomopathological method ${ }^{43}$ Only this method made it

40 Wellman 1992, 169-212; Thomson 1981; Lo Presti 2010b, 163-187.

41 La Mettrie refers to post-mortem examinations (in many cases to corroborate his clinical diagnosis) in chap. 3 (La Mettrie 1755, p. 281), 4 (p. 284), 6 (p. 294), 8 (p. 306), 10 (p. 309), 11 (p. 311), 16 (p. 315) and 19 (p. 317).

42 La Mettrie 1755, 306: 'Après, comme avant la mort, un sang tout à fait dissous et séreux ruisseloit par la bouche et par le nez, et le sang tiré par la veine avoit donné tous les signes d'un scorbut alkalescent. D'où il suit, à mon avis, que ce mal avoit rongé, détruit, ouvert des vaisseaux sanguins, et que c'étoit une dissolution gangreneuse et scorbutique de toute la masse du sang qui avoit causé tous les ravages que je vis à l'ouverture du corps: le grand lobe du foye étoit bordé d'une gangrene livide, le Mésentere, et surtout le Pancréas d'Asellius étoit tout pourri, et il y avoit beaucoup de sang extravasé'.

43 See Foucault 19835, 123: 'L'oeil clinique se découvre une parenté avec un nouveau sens qui lui prescrit sa norme et sa structure épistémologique; ce n'est plus l'oreille tendue vers un langage, c'est l'index qui palpe les profondeurs. D'où cette métaphore du tact par laquelle sans cesse les médecins vont définir ce qu'est leur coup d'oeil. Et dans cette nouvelle image qu'elle se donne d'elle-même, l'expérience clinique s'arme pour explorer un nouvel espace: l'espace tangible du corps, qui est en même temps cette masse opaque où se cachent des secrets, d'invisibles lésions et le mystère même des origines. Et la médecine des symptômes, 
possible to develop an 'observational syntax' with which a doctor could reconstruct a sequence of anatomical alterations and establish a system of objectively verifiable correspondences between this sequence and the sequence of the clinical symptoms. In other words, it was necessary to 'purify experience' in two ways: by introducing the category of 'time' - and therefore a 'genetic' perspective - to the reading of anatomical space and, at the same time, by reorganising this space and reconfiguring the organic structure of the body as a multiplicity of tissular structures, the spatial and functional interconnections of which can be deciphered with analytical techniques similar to those adopted for clinical investigation. Admittedly, this reorganization of the 'syntax' of medical observation and 'purification of experience' are found in La Mettrie only in an embryonic state, so to speak. It is also true that, for clinical empiricism to develop into a universal and coherent method of scientific investigation, it was necessary to wait until the beginning of the nineteenth century and the reform of the anatomical method propounded by Paris medical school and especially by Xavier Bichat, who was one of its leading figures ${ }^{44}$. Nevertheless, if we look at the rise of 'clinical medicine' in Europe from a wider perspective and interpret it, as suggested by Othmar $\mathrm{Kee}^{45}$, as a process over the longue durée, in which many different intellectual and institutional contexts, as well as many different theoretical and methodological factors, contributed in various ways to the gradual definition of the new paradigm, then we will be in a position to consider La Mettrie's medical empiricism as within the framework and fully part of the genealogy of médecine clinique rather than as somewhat vaguely presaging it.

\section{Bibliography}

Alessi, Robert, 'Research Program and Teaching Led by the Master in Hippocrates' Epidemics 2, 4 and 6', in: Manfred Horstmanshoff (ed.), Hippocrates and Medical Education. Selected Papers Presented at the XIIth International Hippocrates Colloquium, Universiteit Leiden, 24-26 August 2005 (Leiden 2010) 119-135

Bloch, Olivier, 'L'héritage libertin dans le matérialisme des Lumières', Dix-huitième siècle 24 (1992) 73-82

Boissier, Raymond, La Mettrie: Médecin, pamphlétaire et philosophe (1709-1751) (Paris 1931)

peu à peu, entrera en régression, pour se dissiper devant celle des organes, du foyer, et des causes, devant une clinique tout entière ordonnée à l'anatomie pathologique'.

44 See Grmek 19948, 222-227. On Xavier Bichat's role in the reform of anatomical practice and the definition of the anatomopathological method, see Haigh1984; Dobo/Role 1989; Foucault 19835, 125-176.

45 Keel 2001. 
Brinkmann, Hellmut, Thomas Sydenham (1624-1689). Die Einflüsse des Hippokratismus auf seine Medizin, PhD diss. Hamburg University (Hamburg 1970)

Brunn, L. von, "Hippokrates und die meteorologische Medizin", Gesnerus 3 (1946-1947) 151-173

Cantor, David (ed.), Reinventing Hippocrates (Aldershot 2001)

Crignon, Claire, Locke médecin. Manuscrits sur l'art médical (Paris 2016)

Daston, Lorraine/Elizabeth Lunbeck, 'Introduction', in: Lorraine Daston/Elizabeth Lunbeck (eds), Histories of Scientific Observation (Chicago/London 2011) 3-4

Deichgräber, Karl, Die Epidemien und das Corpus Hippocraticum (Berlin 1933)

Dewhurst, Kenneth, Dr. Thomas Sydenham (1624-1689). His Life and Original Writings (London 1966) 60-67

Dobo, Nicolas, Role, André, Bichat, la vie fulgurante d'un génie (Paris 1989)

Duchesneau, François, L'empirisme de Locke (The Hague 1973) 8-15

Foucault, Michel, Naissance de la clinique (Paris 19835)

Gougeaud-Arnaudeau, Simone, La Mettrie (1709-1751), le matérialisme clinique (Paris 2008)

Grmek, Mirko D., 'Il concetto di malattia', in: Mirko D. Grmek (ed.), Storia del pensiero medico occidentale, vol. 1. Antichità e medioevo (Rome/Bari 1993) $338-342$

Grmek, Mirko D., Les Maladies à l'aube de la civilisation occidentale: Recherches sur la réalité pathologique dans le monde grec historique, archaïque et classique (Paris 1994)

Grmek, Mirko D., 'Il concetto di malattia', in Mirko D. Grmek (ed.), Storia del pensiero medico occidentale, vol. 3, Dall'età romantica alla medicina moderna (Rome/Bari 1998) 222-227

Haigh, Elizabeth, Xavier Bichat and the Medical Theory of the Eighteenth Century (London 1984)

Hesse, Dorothea, Thomas Sydenham (1624-1689) als Empiriker. Die Beziehung zwischen Sydenham und der Hellenistischen Empirikerschule, PhD diss. Hamburg University (Hamburg 1970)

Jacovides, Michael, 'Locke's Distinction between Primary and Secondary Qualities', in Lex Newman (ed.), The Cambridge Companion to Locke's Essays Concerning Human Understanding (Cambridge 2007) 101-129

Jouanna, Jacques, 'Notice', in: Jacques Jouanna, Mirko D. Grmek, Hippocrate, Epidémies V et VII (Paris 2003) 7-90

Keel, Othmar, L'avènement de la médecine clinique moderne en Europe (1750-1815) (Montreal 2001)

La Mettrie, Julien Offray de, Observations de médecine pratique (Paris 1743)

La Mettrie, Julien Offray de, Observations de médecine pratique, in Euvres de Médecine (Berlin 1755)

La Mettrie, Julien Offray de, Oeuvres philosophiques (Paris 2004)

Langholf, Volker, Medical Theories in Hippocrates: early texts and the 'Epidemics' (Berlin/New York 1990)

Lemée, Pierre, Julien Offray de la Mettrie: Médecin, philosophe, polémiste... sa vie, son oeuvre (Saint-Malo 1954)

Lo Presti, Roberto, 'The physician as Teacher. Epistemic function, cognitive function and the incommensurability of errors', in Manfred Horstmanshoff (ed.), Hip- 
pocrates and Medical Education. Selected Papers Presented at the XIIth International Hippocrates Colloquium, Universiteit Leiden, 24-26 August 2005 (Leiden 2010) 137-167

Lo Presti, Roberto, 'La Mettrie et la réinvention du mécanisme médical', Gesnerus 67 (2010) 163-187

Macchia, Giovanni, 'La Mettrie o il riso dell'automa', in: Id., Il naufragio della speranza. La letteratura francese dall'illuminismo all'età romantica (Milan 1994) 207-211

Pénisson, Pierre, 'La Mettrie à Berlin', in: Sophie Audidière, Jean-Claude Bourdin, Jean-Marie Lardic, Francine Markovits, Yves-Charles Zarka (ed.), Matérialistes français du XVIIIe siècle (Paris 2006) 91-99

Pigeaud, Jackie, 'Le style d'Hippocrate ou l'écriture fondatrice de la médecine', in: Marcel Detienne (ed.), Les savoirs de l'écriture en Grèce ancienne (Lille 1988) 305-329

Pigeaud, Jackie, 'Il medico e la malattia', in: Salvatore Settis (ed.), I Greci. Storia Cultura Arte Società, I, Noi e i Greci (Turin 1996) 785-792

Pinna, Mario, 'Ippocrate fondatore della teoria dei climi', Rivista Geografica Italiana 95 (1988) 3-19

Pomata, Gianna, 'Observation rising: Birth of an Epistemic Genre, 1500-1650', in: Lorraine Daston and Elizabeth Lunbeck (ed.), Histories of Scientific Observation (Chicago/London 2011) 45-80

Reichler, Claude, 'La représentation du corps dans le récit libertin', in: François Moureau, Alain-Marc Rieu (ed.), Discours libertins des Lumières (Paris 1984) $73-82$

Rieu, Alain-Marc, 'La stratégie du sage libertin', in: François Moureau, Alain-Marc Rieu (ed.), Discours libertins des Lumières (Paris 1984) 57-69

Smith, Wesley, The Hippocratic Tradition (Ithaca NY 1979)

Staszak, Jean-François, La géographie d'avant la géographie: le climat chez Aristote et Hippocrate (Paris 1995).

Thomson, Ann, Materialism and Society in the Mid-Eighteenth Century: La Mettrie's 'Discours préliminaire' (Geneva/Paris 1981)

Totelin, Laurence, Hippocratic Recipes. Oral and Written Transmission of Pharmacological Knowledge in Fifth- and Fourth-Century Greece (Leiden 2008)

Wellman, Kathleen, La Mettrie: Medicine, Philosophy, and Enlightenment (Durham and London 1992)

Yeo, In-Sok, 'Hippocrates in the Context of Galen: Galen's commentary on the classification of fevers in "Epidemics" VI', in: Philip van der Eijk (ed.), Hippocrates in context: papers read at the XIth International Hippocrates Colloquium University of Newcastle upon Tyne, 27-31 August 2002 (Boston/Leiden 2005) 433-443 